\title{
REVISTAMATĒRIA
}

\section{Determination of non-isothermal crystallization rate constant of a rotational molding grade LLDPE}

Carlos Alberto Silva de Lima ${ }^{1}$, Marcel Andrey de Goes ${ }^{2}$, Luís Antonio Pinheiro ${ }^{3}$, Benjamim de Melo Carvalho ${ }^{4}$

\footnotetext{
${ }^{1,2}$ Graduate Program in Materials Science and Engineering - State University of Ponta Grossa - UEPG e-mail: carlos_de_lima@gmail.com; marcel.pg@hotmail.com

${ }^{3,4}$ Materials Engineering Department - UEPG, Av.Carlos Cavalcanti 4748, Uvaranas, CEP 84030-900, Ponta Grossa -PR. e-mail: lapinheiro@uepg.brbenjamim@uepg.br
}

\begin{abstract}
The purpose of the present paper was to test the validity of the nonlinear regression method for calculating the non-isothermal crystallization rate constant of the Nakamura's model of a rotational molding grade LLDPE directly from non-isothermal crystallization experiments carried out in a single cell DSC. Cooling rates of 50,40,30, 20, 10 and $5 \mathrm{oC} / \mathrm{min}$ were used with samples of $3.0 \mathrm{mg}$ under nitrogen atmosphere. Here, good agreement was observed between the experimental relative crystallinity curves and the simulated ones using the calculated parameters by nonlinear regression. It shows that this method can be used to determine the Nakamura's non isothermal rate constant for using in simulation of the cooling phase of rotational molding. In this paper it was used 10-3, 10-4 and 10-14 as the initial crystallinity in the Nakamura's model. However the best average results for all cooling rates was obtained when 10-4 was used. Average spherulitic dimensions of LLDPE studied in this paper did not change significantly with different cooling conditions.
\end{abstract}

Keywords: Nonlinear regression method, non-isothermal crystallization, Nakamura's model, linear low density polyethylene, rotational molding.

\section{INTRODUCTION}

One of the difficulties for incorporation of the crystallization phenomenon in softwares for simulation of polymer processing is the necessity of easy and reliable methods for determining the parameters of a given kinetic model chosen to describe the crystallization process.

The nonlinear regression method can be used for obtaining the parameters of kinetic crystallization models, such as Nakamura's [ $\underline{1}, \underline{2}$ ], Kamal and Chu's []ㅡ, Dietz [4] and Malkin's [ㄷ], directly from the nonisothermal crystallization data obtained by Differential Scanning Calorimeters. Results of this method are usually considered good. However, literature mentions unsatisfactory results related to nonlinear regression, but this behavior is more likely associated to limitations of the crystallization model in describing the nonisothermal crystallization process of the polymer than by the nonlinear regression method itself $[\underline{4}, \underline{7}]$. One advantage of nonlinear regression is that its procedure for calculating the crystallization kinetic constant is faster than the master curve approach [ $[$ ]

The rotational molding is highly dependent on the raw material and it could not exist without adequate polymers for typical conditions of this process. To be rotomolded, a polymer must have heat resistance in order to avoid chemical oxidative degradation due to long residence time in the oven. The most common material used in the process is polyethylene (PE), and in this class stands Linear Low Density Polyethylene (LLDPE) [9]. This polymer is semicrystalline and its crystallization during the cooling phase of rotational molding affects both properties and processing conditions.

Therefore, the purpose of the present study was to test the validity of the nonlinear regression method for calculating the non-isothermal crystallization rate constant of the Nakamura's model of a rotational molding grade LLDPE directly from non-isothermal crystallization experiments carried out in a single cell 
Hot Stage-DSC. This equipment reaches controlled cooling rates up to $100{ }^{\circ} \mathrm{C} / \mathrm{min}$ and allows the in-situ recording of the developed crystalline microstructure during cooling. Therefore, it is an interesting alternative for studying non-isothermal crystallization process of polymers.

\section{MATERIALS AND METHODS}

\section{Materials}

A specific Linear low density polyethylene (LLDPE) to be used in rotational molding process was used in this study. This polymer, kindly supplied by Braskem S.A, has melting point of $125^{\circ} \mathrm{C}$ and melt flow index equal to $4.2 \mathrm{~g} / 10 \mathrm{~min}[9]$.

\section{Methods}

A Differential Scanning Calorimeter DSC 600 Hot Stage from Linkam was used to study the non-isothermal crystallization kinetics of LLDPE. About $3.0 \mathrm{mg}$ of the material, sealed in an aluminum pan, was heated to $200^{\circ} \mathrm{C}$ and held at this temperature for 5 minutes before cooling at different rates $(50,40,30,20,10$ and 5 ${ }^{\circ} \mathrm{C} / \mathrm{min}$ ) to $30^{\circ} \mathrm{C}$ under nitrogen atmosphere. According the procedure recommended by Isayev et al. [10-12] the experiments were carried out with the same sample for all the six cooling rates in order to obtain good repeatability for the heat transfer conditions between DSC furnace and the aluminum pan.

The normal procedure for obtaining the non-isothermal crystallization rate constant was applied using the experimental data. Therefore, it was necessary to define the temperature of the onset of crystallization for each cooling rate. The relative crystallinity $(\theta)$ vs. temperature curve was determined (as well as the corresponding $\theta$ vs. time curve) for each cooling rate by partial area calculation in the experimental DSC curve. In this way, the experimental derivative curve $\mathrm{d} \theta / \mathrm{dt}$ vs. temperature was obtained.

Nonlinear regression method was used to obtain the parameters $\left(1 / \mathrm{t}_{1 / 2}\right)_{0}$ and $\mathrm{Kg}$ in equation 1 by fitting the differential form of Nakamura's model, given by equation 2 , to the experimental $\mathrm{d} \theta / \mathrm{dt} v \mathrm{vs}$. $\mathrm{T}$ :

$$
\begin{aligned}
& K(T)=(\ln 2)^{1 / n}\left(\frac{1}{t_{1 / 2}}\right)_{0} \exp \left(\frac{-U / R}{T-T_{\infty}}\right) \exp \left(\frac{-K_{g}}{T \Delta T f}\right) \\
& \frac{d \theta}{d t}=n K(T)(1-\theta)[-\ln (1-\theta)]^{n-1 / n}
\end{aligned}
$$

where $(1 / \mathrm{t} 1 / 2)_{0}$ is a pre-exponential factor that includes all terms independent of temperature; $\mathrm{U}$ is the activation energy for the transport of crystallizing units across the phase boundary; $\mathrm{Kg}$ is the nucleation exponent; $\mathrm{T} \infty=\mathrm{Tg}-30 \mathrm{~K}$ is the temperature below which molecular transport ceases; $\mathrm{R}$ is the universal gas constant; $\Delta \mathrm{T}=\mathrm{Tm}^{0}-\mathrm{T}$ is the degree of supercooling, $\mathrm{f}=2 \mathrm{~T} /\left(\mathrm{Tm}^{0}+\mathrm{T}\right)$ is a correction factor accounting for the reduction in the latent heat of fusion as the temperature is decreased, and $\mathrm{Tm}^{0}$ is the equilibrium melting temperature.

\section{RESULTS AND DISCUSSION}

The $\theta$ vs. temperature curve was determined by applying the method of partial area calculation. Fig. 1 shows the experimental crystallization rate $\mathrm{d} \theta / \mathrm{dt}$ as a function of temperature for the six different cooling rates used in this study. 


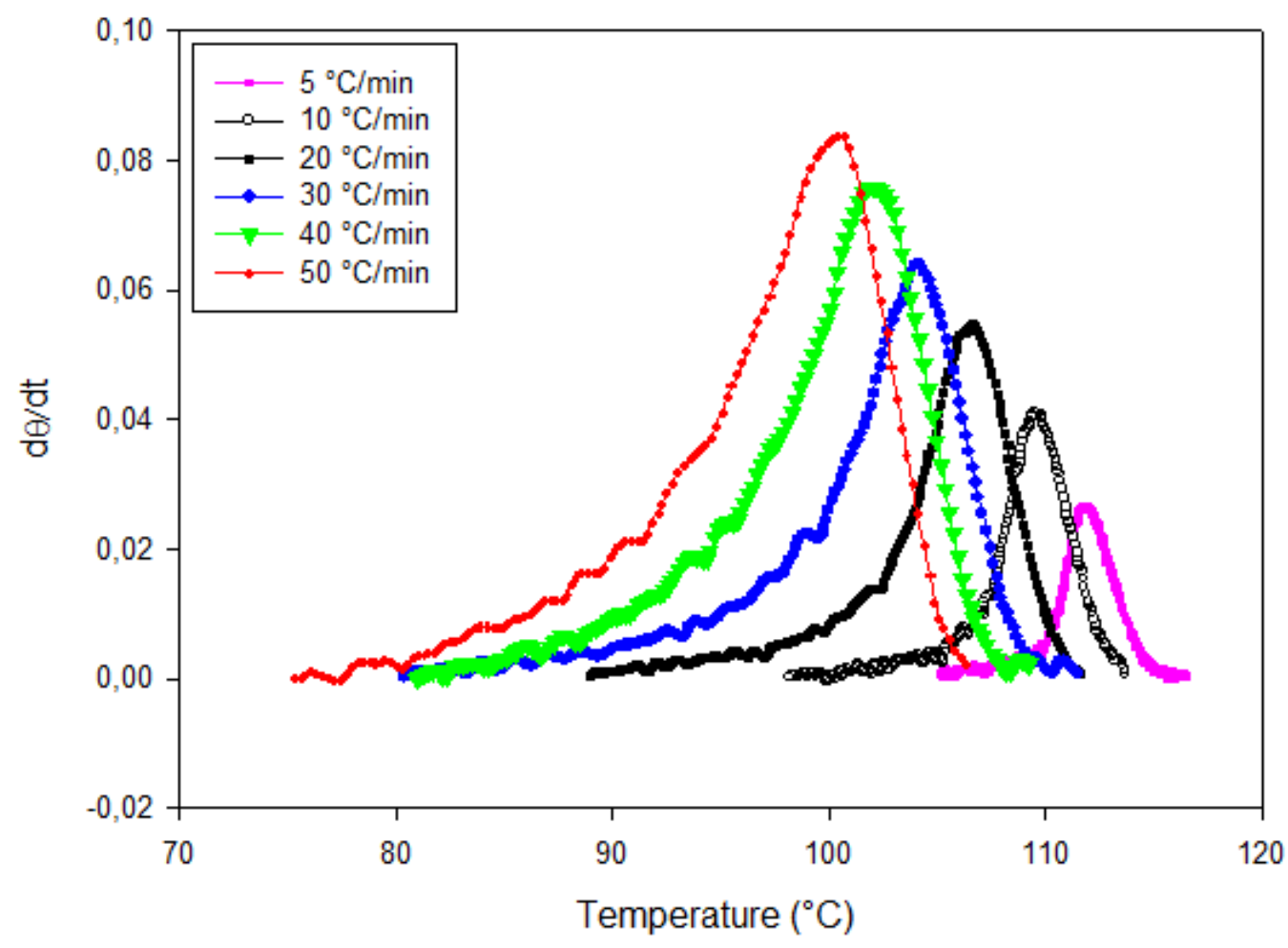

Figure 1: Crystallization rates $\mathrm{d} \theta / \mathrm{dt}$ as a function of temperature for LLDPE sample cooled at different cooling rates.

As expected, higher cooling rates led to larger and broader peaks and lower onset and peak temperatures, as well as higher crystallization rates. The non-isothermal crystallization data was used to obtain the parameters $\mathrm{Kg}$ and $\left(1 / \mathrm{t}_{1 / 2}\right)_{0}$ by nonlinear regression method. Table 1 shows that the $\mathrm{Kg}$ obtained from the nonlinear regression are different for all six cooling rates. The $\left(1 / \mathrm{t}_{1 / 2}\right)_{0}$ for the six cooling conditions are different too, mainly for $50{ }^{\circ} \mathrm{C} / \mathrm{min}$. For this last cooling rate, the kinetic parameters are much higher than for the other cooling conditions. Using the calculated $\mathrm{K}(\mathrm{T})$ and assuming $\mathrm{n}$ equal to 3 , the differential form of the Nakamura equation, given by Equation 2, could be used to simulate the $\mathrm{d} \theta / \mathrm{dt}$ vs. T curves, which are integrated to obtain the $\theta$ vs. T curves. These simulated data were compared to the experimental ones to check the quality of the kinetic parameters calculated by non-linear regression.

Table 1: Crystallization kinetic parameters of LLDPE obtained by the nonlinear regression.

\begin{tabular}{|c|c|c|}
\hline Cooling Rate & $\left(1 / t_{1 / 2}\right)_{0}\left(s^{-1}\right)$ & $\mathrm{Kg}\left(\mathrm{K}^{2}\right)$ \\
\hline $5^{\circ} \mathrm{C} / \mathrm{min}$ & 1,65 & $2,49 \times 10^{-5}$ \\
\hline $10^{\circ} \mathrm{C} / \mathrm{min}$ & 1,46 & $9,9 \times 10^{-7}$ \\
\hline $20^{\circ} \mathrm{C} / \mathrm{min}$ & 1,13 & $4,4 \times 10^{-7}$ \\
\hline $30^{\circ} \mathrm{C} / \mathrm{min}$ & 0,98 & $4,5 \times 10^{-8}$ \\
\hline $40^{\circ} \mathrm{C} / \mathrm{min}$ & 0,75 & $2,2 \times 10^{-8}$ \\
\hline $50^{\circ} \mathrm{C} / \mathrm{min}$ & 15,38 & $4,1 \times 10^{4}$ \\
\hline
\end{tabular}

The interval between $5 \%$ and $75 \%$ of relative crystallinity on each non-isothermal crystallization curve was used to determinate the kinetic parameters by nonlinear regression. Fig. 2 and 3 show the comparison between experimental and simulated curves at different cooling rates. 
Fig. 4 shows all curves of relative crystallinity as a function of temperature. In general, simulated curves presented good agreement with experimental ones (mainly at intermediate rates of 40, 30, 20 and 10 ${ }^{\circ} \mathrm{C} / \mathrm{min}$ ). In each case, the major divergence between experimental and simulated curves appears at the final stages of the crystallization process. It is not an unexpected behavior once Nakamura's model usually has difficulties to describe the end of crystallization process [] ].

The differential form of the Nakamura's Model, equation 2, shows that for $\theta$ equal to zero, the rate of crystallization $\mathrm{d} \theta / \mathrm{dt}$ is zero. In this case, a negligible $\theta_{\mathrm{t}=0}$ must be used in equation 2 to obtain the simulated curves, albeit different from zero. Otherwise, $(\mathrm{d} \theta / \mathrm{dt})_{\mathrm{t}=0}$ will be zero and $\theta_{t+\Delta t}$ will always be zero, as clearly demonstrated by Galera et al [] $]$. They showed that $\theta_{\mathrm{t}=0 \text { equal }}$ to $10^{-3}$ was a good value to be used instead of $10^{-14}$ suggested by Chan [10]. Therefore in the present study it was tested $10^{-3}, 10^{-4}$ and $10^{-14}$ as the initial crystallinity in the Nakamura's model. However the best average results for the set of cooling rates was obtained when $10^{-4}$ was used as the initial relative crystallinity and this value was applied for calculating the simulated curves shown in Figures 2, 3 and 4.

As mentioned by Galera et al []], the Nakamura's Model presents an extremely slow initial crystallization rate. Therefore, in the initial stages of crystallization, it takes a considerable amount of time to go from $\theta=10^{-14}$ to $\theta=10^{-3}$. In this case, the use of $\theta_{\text {initial }}$ equal to $10^{-3}$ or $10^{-4}$ is more convenient because it can be used with a Tic (temperature at the beginning of the crystallization process in DSC experiments) that is much easier to define than the one coherent with $\theta=10^{-14}$.

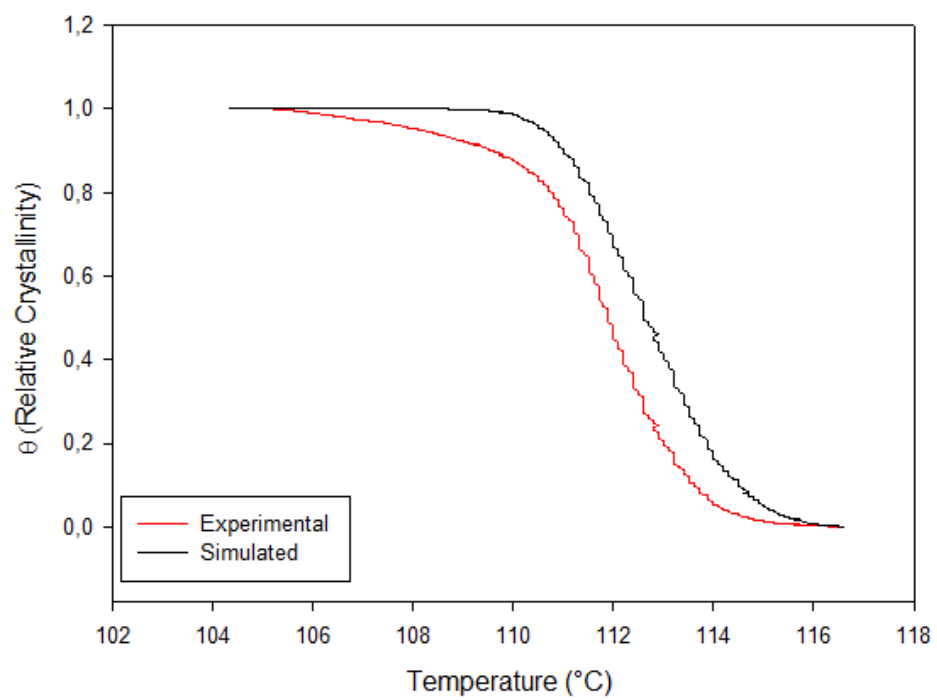

(A)

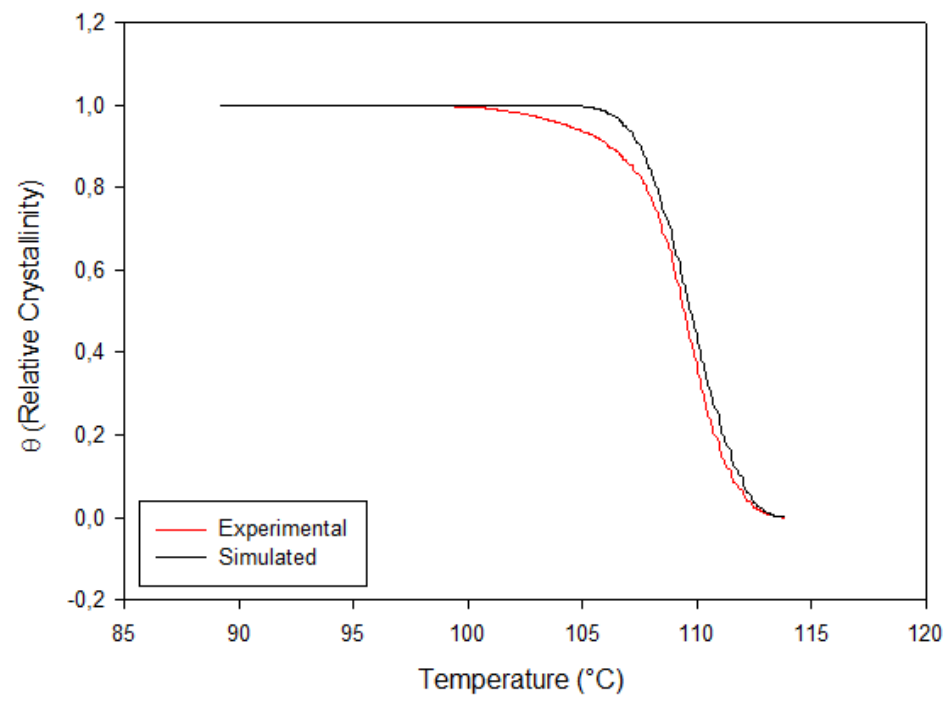

(B) 
LIMA, C. A.S.; GOES, M. A.; PINHEIRO, L. A.; CARVALHO, B. M. revista Matéria, v.20, n.1, pp. 203 - $211,2015$.

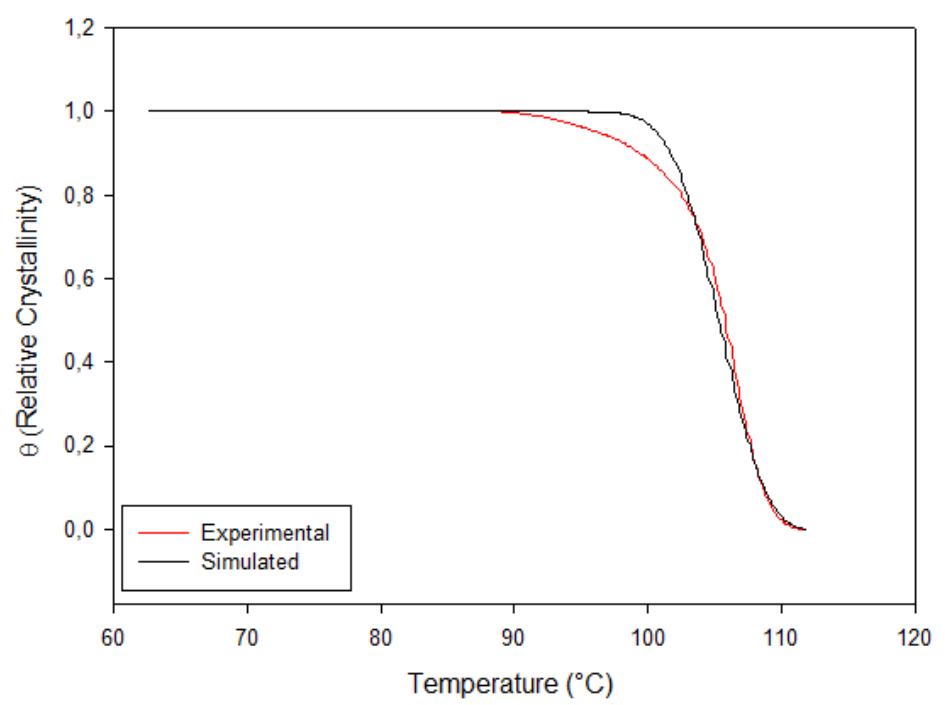

(C)

Figure 2: Comparison between experimental and simulated relative crystallinity curves as a function of temperature generated by the Nakamura's model: (A) $5{ }^{\circ} \mathrm{C} / \mathrm{min}$; (B) $10{ }^{\circ} \mathrm{C} / \mathrm{min}$ and (C) $20^{\circ} \mathrm{C} / \mathrm{min}$.

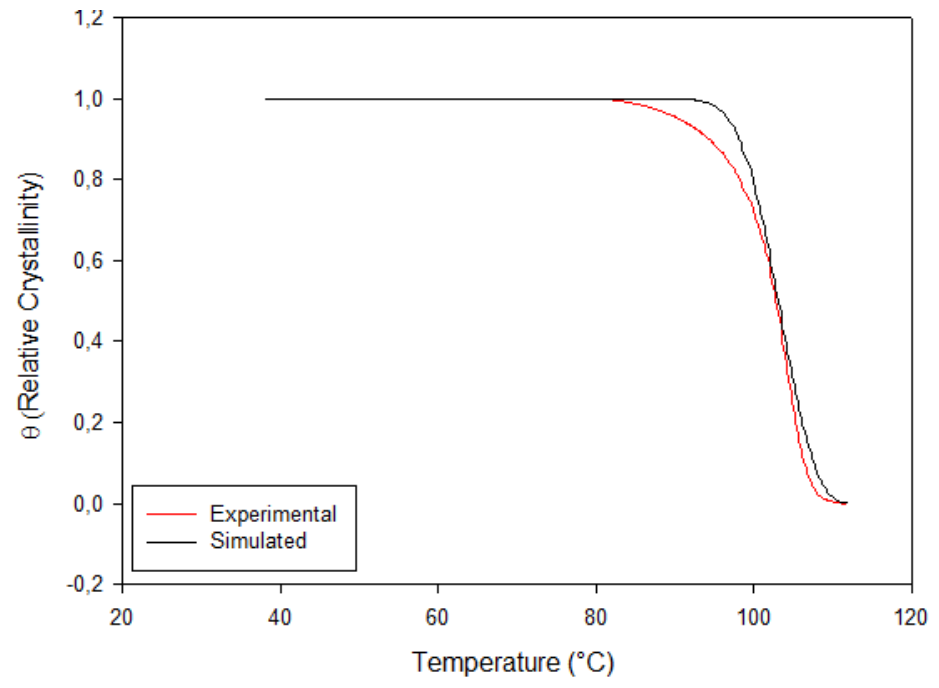

(A)

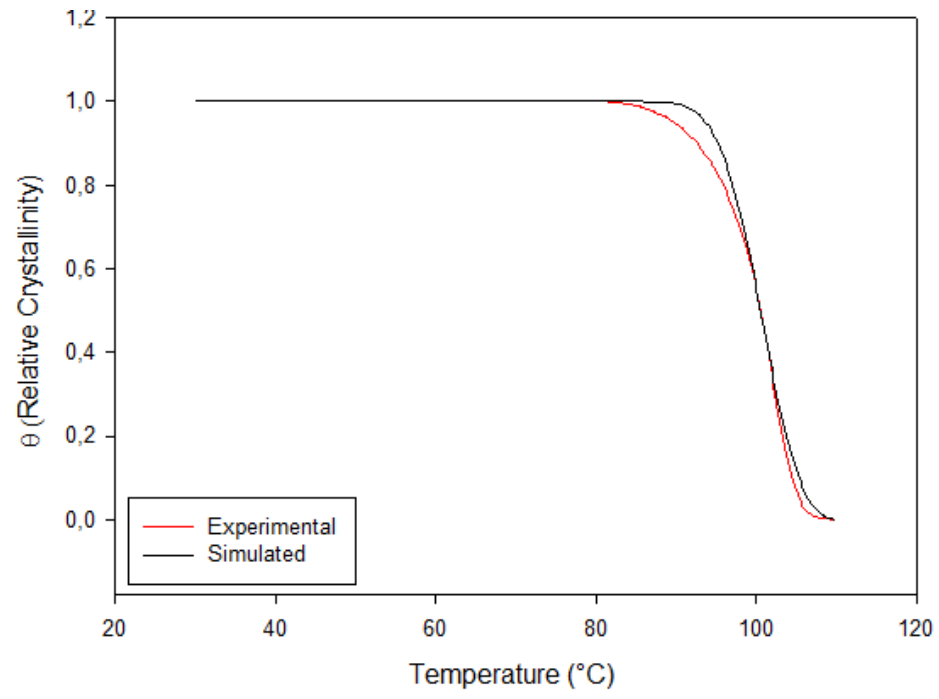

(B) 


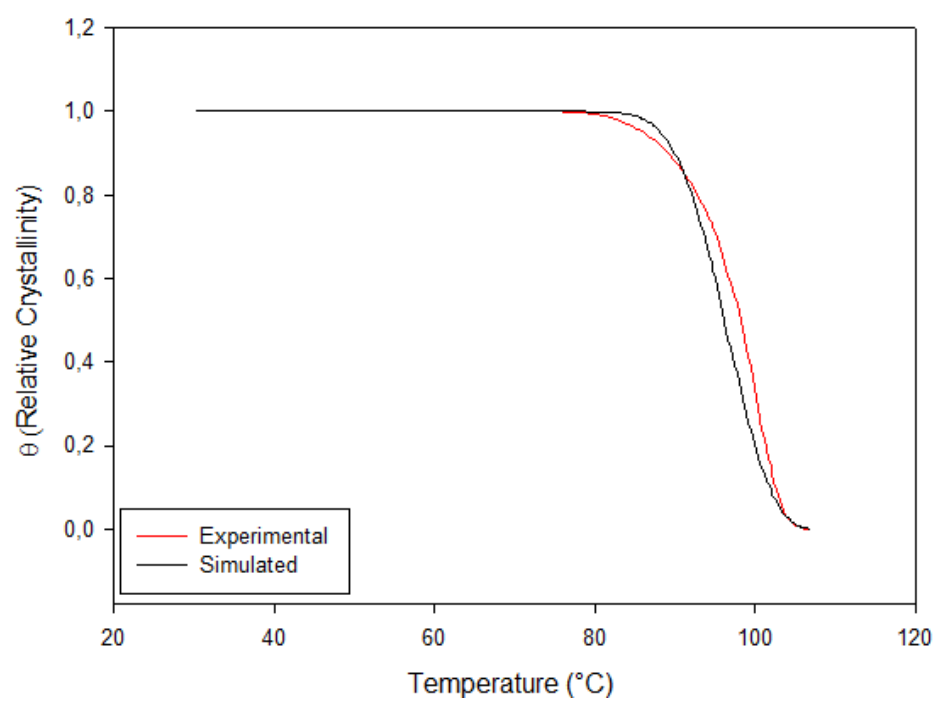

(C)

Figure 3: Comparison between experimental and simulated relative crystallinity curves as a function of temperature generated by the Nakamura's model: (A) $30^{\circ} \mathrm{C} / \mathrm{min}$; (B) $40{ }^{\circ} \mathrm{C} / \mathrm{min}$ and (C) $50{ }^{\circ} \mathrm{C} / \mathrm{min}$.

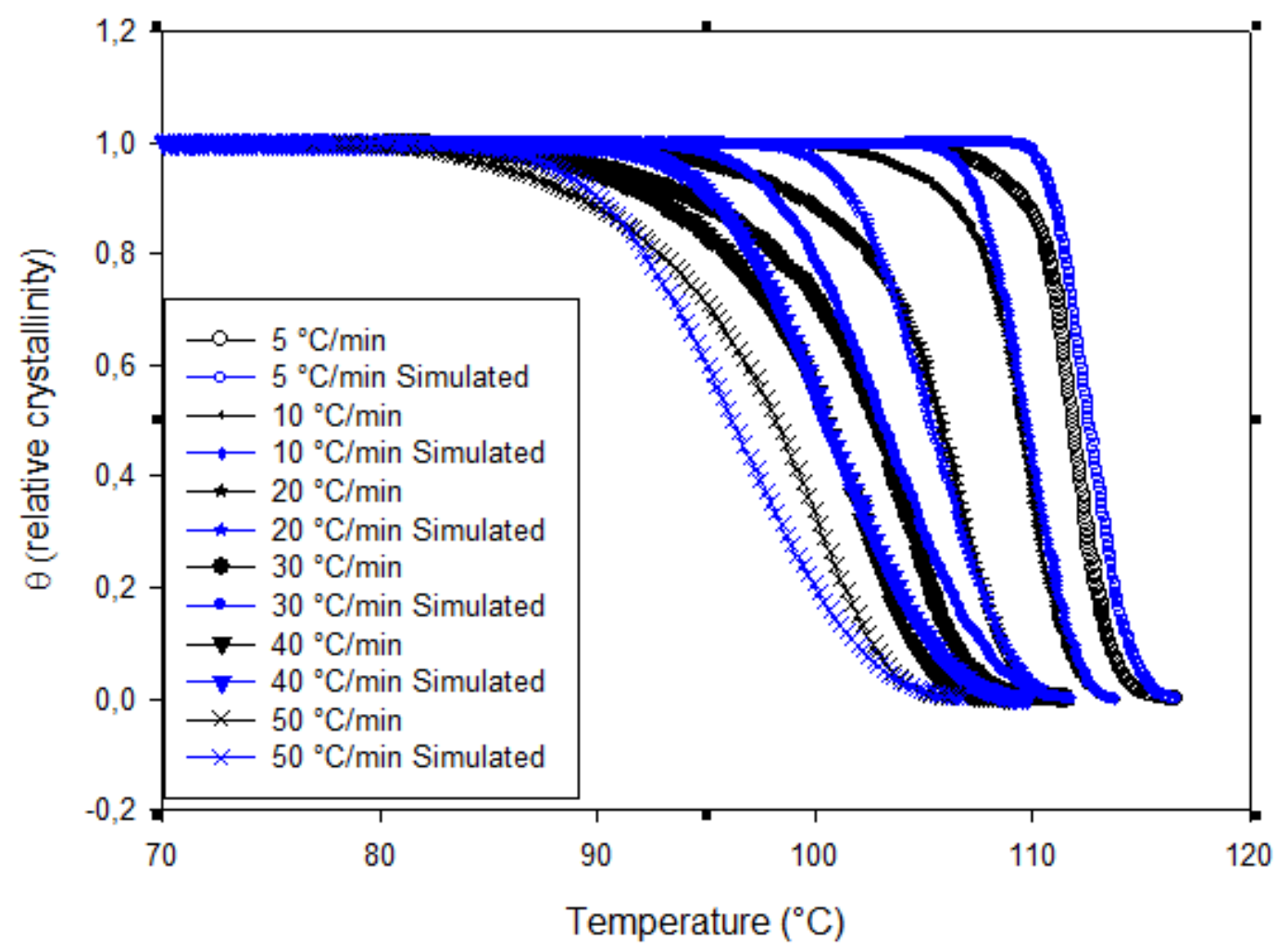

Figure 4: Comparison between experimental and simulated relative crystallinity curves for all cooling rates.

Figure 5 shows a sequence of images taken during cooling at $30^{\circ} \mathrm{C} / \mathrm{min}$. It is possible to note the formation of the crystalline phase along the sample as a function of temperature and it is interesting to compare this sequence with crystallization evolution in Figure $3 \mathrm{~A}$. Figure $5 \mathrm{~A}$ shows that at $133{ }^{\circ} \mathrm{C}$ the crystallization process has not started yet, fact coherent with Figure $3 \mathrm{~A}$. At $107{ }^{\circ} \mathrm{C}$ it is clear that a significant degree of crystallinity is already developed in the sample (Figure 3A) and this hypothesis was confirmed by real-time observation on microscope at this temperature. In contrast, the visualization of crystalline phase is not so clear in Figure 5B because the loss of resolution in micrograph compared to the image observed on 
microscope and due to the small crystalline structures developed in this sample. However, an increase in the depolarized light intensity (not shown here) also confirmed that the crystallization process had already started at $107{ }^{\circ} \mathrm{C}$. The final crystalline morphology for this sample cooled at $30^{\circ} \mathrm{C} / \mathrm{min}$ is shown in Figure 5C.

Figure 6 shows the morphology at $30{ }^{\circ} \mathrm{C}$ for LLDPE cooled at $5{ }^{\circ} \mathrm{C} / \mathrm{min}$ from the melt state. It is possible to observe that nucleation density is still high and the average spherulitic size did not increase significantly when compared to that developed under cooling of $30^{\circ} \mathrm{C} / \mathrm{min}$, as shown on Figure $5 \mathrm{C}$.

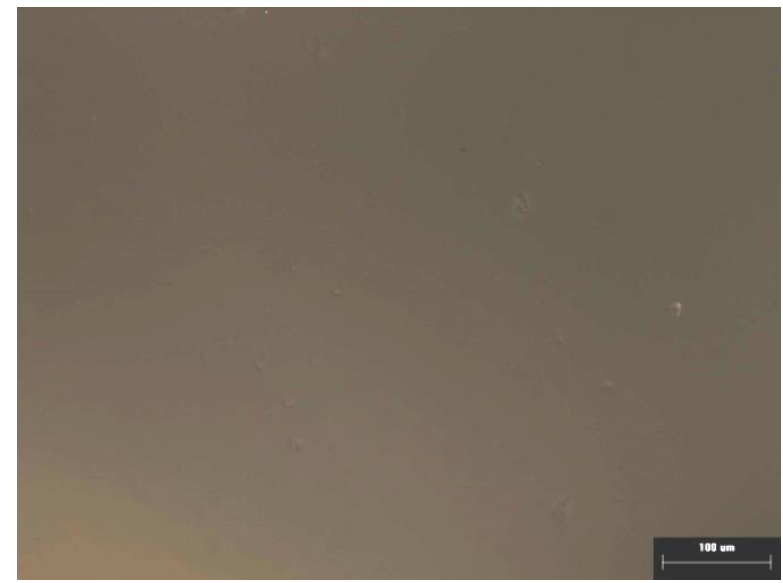

(A)

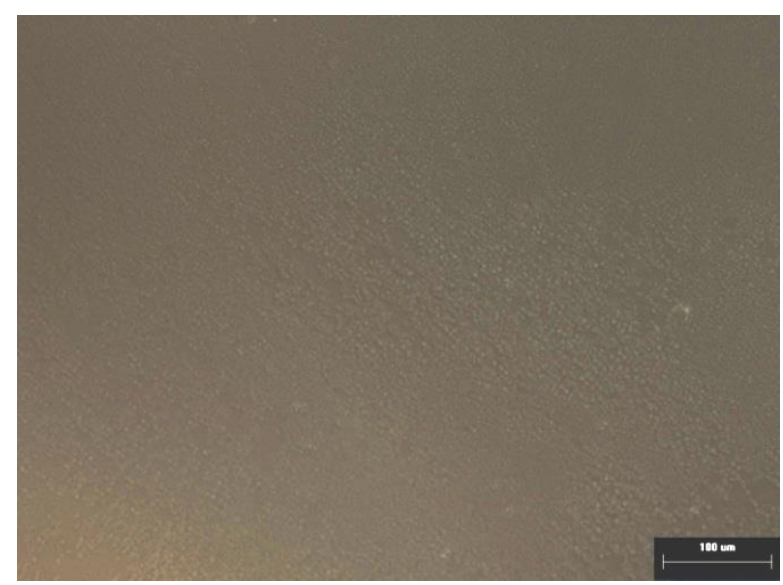

(B)

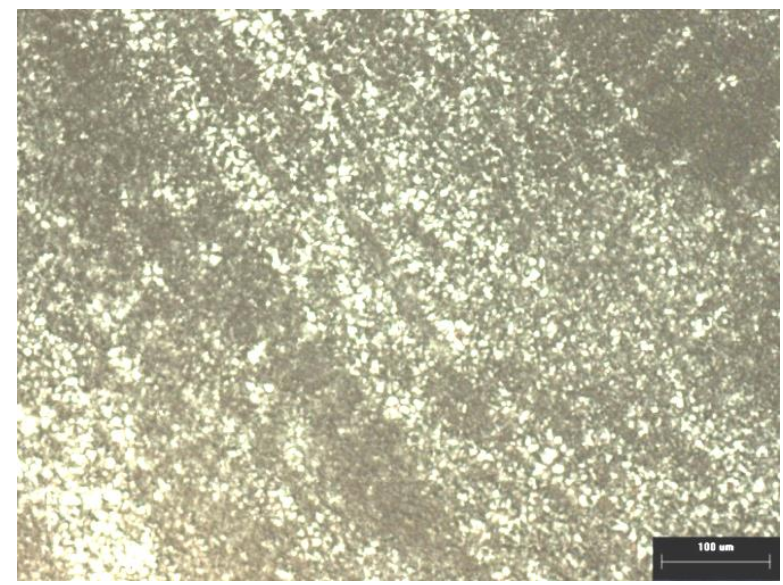

(C) 
Figure 5: Development of microstructure of LLDPE for the cooling rate of $30^{\circ} \mathrm{C} / \mathrm{min}$ at: (A) $133{ }^{\circ} \mathrm{C}$; (B) $107^{\circ} \mathrm{C}$ and (C) $30^{\circ} \mathrm{C}$.

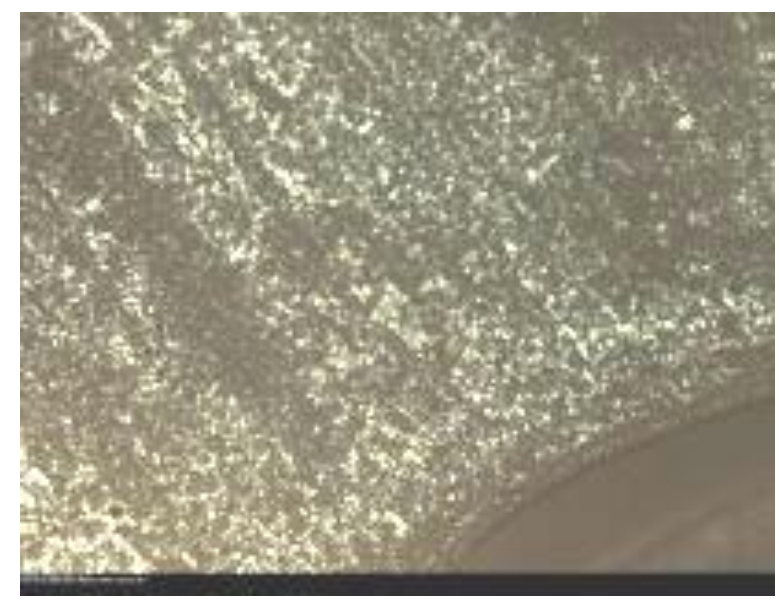

Figure 6 : Microstructure at $30^{\circ} \mathrm{C}$ for LLDPE cooled at of $5{ }^{\circ} \mathrm{C} / \mathrm{min}$.

\section{CONCLUSIONS}

A good agreement was obtained between the experimental and simulated relative crystallinity curves using calculated parameters by nonlinear regression. It shows that this method can be used to determine the Nakamura's non isothermal rate constant for using in simulation of the cooling phase of rotational molding. In the present work it was tested $10^{-3}, 10^{-4}$ and $10^{-14}$ as the initial crystallinity in the Nakamura's model. However the best average results for the set of cooling rates was obtained when $10^{-4}$ was used. For the grade of LLDPE used in the present work spherulitic dimensions did not change significantly with different cooling conditions. The single cell Hot Stage-DSC used in this paper showed to be an interesting alternative for studying non-isothermal crystallization process of polymers.

\section{ACKNOWLEDGMENTS}

The authors would like to thank Braskem S.A. by supplying the LLDPE and Fundação Araucária and CAPES for the financial support.

\section{BIBLIOGRAPHY}

[1] NAKAMURA, K., KATAYAMA, K., AMANO, T. "Some aspects of nonisothermal crystallization of polymers. II. Consideration of the isokinetic condition”, Journal of Applied Polymer Science, v.17, n.4, pp.1031-1041, April. 1973.

[2] PATEL, R.M, SPRUIELL, L.J.E. "Crystallization kinetics during polymer processing: analysis of available approaches for process modeling”, Polymer Engineering and Science, v. 31, n.10, pp.730-738. May. 1991. [3] PÉREZ, C. J., ALVAREZ, V.A., STEFANI, P. M., et al., "Non-isothermal crystallization of materbiz/clay nanocomposites", Journal of Thermal Analysis, v.88, n.3, pp. 825-832, July. 2007.

[4] ALVAREZ, V. A., STEFANI, P.M., VÁZQUEZ, A. "Non-isothermal crystallization of polyvinylalcoholco-ethylene", Journal of Thermal Analysis, v. 79, n.1, pp.187-193, Feb. 2005.

[5] FRIEDL, C.F., MCCAFFEREY, N.J. “Crystallization prediction in injection molding”, In: SPE ANTEC Technical Papers, pp.330-332, Montreal, May. 1991.

[6] CARVALHO, B., BRETAS, R.E.S., "Crystallization kinetics of a PEEK/LCP blend”, J. Appl. Polym. Sci., v.55, n.2, p.233. Jan. 1995.

[7] MUBARAK, Y, HARKIN-JONES, EMA, MARTIN, P. J, et al., "Modeling of non-isothermal crystallization kinetics of isotactic polypropylene", Polymer, v.42, n.7, pp.3171-3182, March. 2001.

[8] GALERA, V. V., LUCAS, A.L., CARVALHO, B. M., "Determination of Non-Isothermal Crystallization Rate Constant for Pseudo-Experimental Calorimetric Data”, Materials Research, v.12, n.2, pp. 151-157, June. 2009. 
[9] COMISSO, T. B., LIMA, C.A.S., CARVALHO, B. M., "Estudo Experimental do Processo de Rotomoldagem de PELBD: Efeitos sobre a Morfologia e Estabilidade Dimensional”, Polímeros, v.23, n.1, pp. 97-107, Feb. 2013.

[10] CHAN, T.V., SHYU, G.D., ISAYEV A.I. "Master curve approach to polymer crystallization kinetics", Polymer Engineering and Science, v.35, n.9, pp.733-740, May. 1995.

[11] CARVALHO, B. M, BRETAS R. E. S. "Determinação da constante cinética de cristalização não isotérmica de polipropilenos modificados com ácido acrílico e anidrido maleico", Polímeros, v.16, n.4, pp.305311, October. 2006.

[12] MARINELLI, A. L, CARVALHO, B. M, BRETAS, R.E.S. "Evaluation of the master curve approach for the non-isothermal crystallization of PP/EPR", UEPG Ciências Exatas e da Terra, Ciências Agrárias e Engenharia, v.10, n.3, pp.13-17, Dez. 2004. 